\title{
Distribution and Year-class Strength of Juvenile Redfish, Sebastes sp., on Flemish Cap in the Winters of 1978-82
}

\author{
G. R. Lilly and C. A. Gavaris ${ }^{1}$ \\ Department of Fisheries and Oceans, Fisheries Research Branch \\ Northwest Atlantic Fisheries Centre, P. O. Box 5667 \\ St. John's, Newfoundland, Canada A1C 5X1
}

\begin{abstract}
Distribution and abundance of juvenile redfish, Sebastes sp., on Flemish Cap in the winters of 1978-82 were estimated from catches during research bottom-trawl surveys and from numbers of redfish in stomachs of cod caught during these surveys. Two modal groups in the redfish length frequencies $(7-8 \mathrm{~cm}$ and $11-12 \mathrm{~cm})$ were assumed to represent 1-and 2-year-old fish respectively, but ageing remains uncertain. Both size-groups were found primarily in depths of 200-300 m, with major concentrations on the southern slope of the bank.
\end{abstract}

The 1978 year-class, which appeared to be abundant in cod stomachs and moderately abundant in trawl catches in 1979, was not abundant in subsequent years, indicating that mortality of juvenile redfish can be high. The 1980 and 1981 year-classes, which appear to be stronger than the 1978 year-class on Flemish Cap, have been noted to be strong in other parts of the Northwest Atlantic, particularly on St. Pierre Bank, on the Scotian Shelf, and in the Gulf of St. Lawrence.

\section{Introduction}

In studies of factors affecting recruitment in marine fishes, there tends to be little emphasis on the juvenile stage (Bakun and Parrish, 1980), primarily because of difficulties in sampling. However, a measure of the strength of year-classes at the early juvenile stage is necessary for determining the success of cohorts passing through the larval stage and for determining whether significant and variable mortality, which contributes to year-class variability, occurs between completion of the larval stage and recruitment to the fishery. Studies in freshwater habitats have shown that interspecific and intraspecific predation on juvenile fish may be an important factor influencing ultimate year-class strength (Forney, 1976; Bagenal, 1977; Nielsen, 1980; Mann, 1982).

Proposals for sampling during the international program of research toward understanding recruitment processes of Atlantic cod, Gadus morhua, and Atlantic redfishes, Sebastes sp., on Flemish Cap (NAFO Division $3 \mathrm{M}$ ) initially included quantitative sampling of juveniles in March and September with the use of special gears (ICNAF, 1977), but this part of the program was later omitted. However, there still remains the need to obtain an early indication of the fate of larvae studied during spring and summer surveys (Anderson and Akenhead, 1981) and to monitor the success of cohorts during the juvenile stage. Mortality of juvenile redfish may be particularly significant, because they are preyed upon intensively by cod during the long juvenile period (Templeman, 1976; Lilly, 1980).
The purpose of this paper is to describe the length composition, distribution and relative abundance of young redfish on Flemish Cap based on bottom-trawl surveys in the winters of 1978-82. Because these juveniles may not be fully available to the research trawl, the catch rates during these surveys may not be reliable indicators of abundance. Therefore, the quantities of young redfish found in cod stomachs were used to provide a second indicator of distribution and abundance.

The specific identity of the redfish described in this paper is uncertain. Examination of meristic and morphological characters in adult redfishes has shown that three species (Sebastes mentella, S. fasciatus and S. marinus) occur on Flemish Cap, with S. mentella being the most abundant (Templeman, 1976; Ni, 1981b, 1982; Ni and McKone, 1983). However, it is not yet possible to distinguish between juveniles of these species by the above-noted characters (Ni, MS 1982). In future studies, the identity of small redfish may possibly be determined by examination of the morphology of the gasbladder musculature, which is considered to be an effective but inconvenient discriminator $(\mathrm{Ni}$, 1981a; Power and Ni, 1982).

\section{Materials and Methods}

Cod and redfish were captured during stratifiedrandom bottom-trawl surveys of Flemish Cap by the chartered research trawler Gadus Atlantica during January-February of 1978 to 1982 (Table 1). Some additional material was obtained from a few trawl sets

'Present address' 23 Howley Avenue Ext., St. John's, Newfoundland, Canada. 
TABLE 1. Survey information relevant to this study of small redfish on Flemish Cap, 1978-82.

\begin{tabular}{llcc}
\hline Year & Survey dates & $\begin{array}{c}\text { Number } \\
\text { of sets }^{\mathrm{a}}\end{array}$ & $\begin{array}{c}\text { Number of cod } \\
\text { stomachs examined }\end{array}$ \\
\hline 1978 & 27 Jan-12 Feb & 112 & 353 \\
1979 & 29 Jan-18 Feb & 76 & 80 \\
1980 & 6-21 Jan & 103 & 439 \\
1981 & 7-22 Jan & 113 & 485 \\
1982 & 28 Jan-14 Feb & 108 & 475 \\
\hline
\end{tabular}

a Only sets in strata 501-514 (Pitt et al., 1981) were considered.

b Numbers of cod $\geqslant 30 \mathrm{~cm}$ fork length; very few cod were from strata 515-519.

in March and May 1979. The Engel high-rise otter trawl, with 29-mm mesh liner in the codend, was towed at 3.5 knots $(180 \mathrm{~m} / \mathrm{min})$ for $30 \mathrm{~min}$ at each fishing station. Fishing was conducted on a 24-hr basis. Cod and redfish were measured as fork length (snout to mid-fork of caudal fin) to the nearest centimeter.

The cod-stomach sampling design varied over the 5 -year period. During the first four winter surveys (1978-81), field observations involved the recording of the two major food items in the stomachs of cod which were selected haphazardly from the catches throughout each survey. The results of these observations were reported by Lilly (MS 1981) and are not discussed in this paper. Additionally, stomachs were collected for detailed laboratory examination from some of the remaining cod. In 1978 and 1979, these cod were selected haphazardly, with an effort being made to sample a wide range of fish size throughout the survey area. In 1980 and 1981, the cod for detailed examination were selected on a stratified-random basis (three cod per 10-cm length group) from the remaining fish in each catch. In 1982, a stratified-random sample was taken from every trawl set. The sample size in 1979 was considerably smaller than in other years (Table 1).

Most cod stomachs chosen for detailed examination were excised at sea and preserved in $10 \%$ formalin, but some cod were frozen whole and thawed in the laboratory before removal and preservation of stomachs. Examination in the laboratory involved separation of food items into taxonomic categories. Fish prey were counted and their total lengths measured to the nearest millimeter. Many small redfish had frayed or missing caudal fins but intact vertebral columns. During 1978-80, such partly digested specimens were not measured, but in 1981 and 1982, the total lengths were estimated from the following relationship, which was derived from paired measurements of standard length $(\mathrm{SL})$ and total length (TL) of specimens with intact caudal fins:

$$
\mathrm{TL}=1.270 \mathrm{SL}^{0.986} \quad\left(\mathrm{n}=128, \mathrm{r}^{2}=0.99\right)
$$

In 1978-81, almost all juvenile redfish from cod stomachs belonged to a single size-class. When it was realized part way through the examination of stomachs collected in 1982 that two size-classes were represented, a somewhat arbitrary division between sizeclasses was made at $90 \mathrm{~mm}$. Subsequently, all unmeasurable juvenile redfish which appeared to be less than $125 \mathrm{~mm}$ total length were assigned to one of the two size-classes. Thus, counts of juvenile redfish in cod stomachs by size-class were available for most but not all of the catches.

Derivation of an index of abundance of young redfish based on recoveries from cod stomachs is complex, because the ingestive capacity of cod increases rapidly with size (Fig. 1). Adjustment to a standard size was not attempted, because the feeding behavior of cod is not well understood; for example, large cod may tend to ignore juvenile redfish and thus not feed to capacity even when juvenile redfish are very abundant. The index could also be calculated by using cod of a narrow size range, but samples from individual sets tended to be too small to allow this restriction. For this paper, the index of abundance was expressed simply as the mean number of juvenile redfish of a specified size-group recovered from cod greater than $29 \mathrm{~cm}$ in length.

The catch rate of juvenile redfish for each survey was expressed as the stratified mean (arithmetic) number per tow, using catches from strata $501-514$, as defined by Pitt et al. (1981). Strata 515-519 were not adequately surveyed in 1982 and were omitted from the analysis.

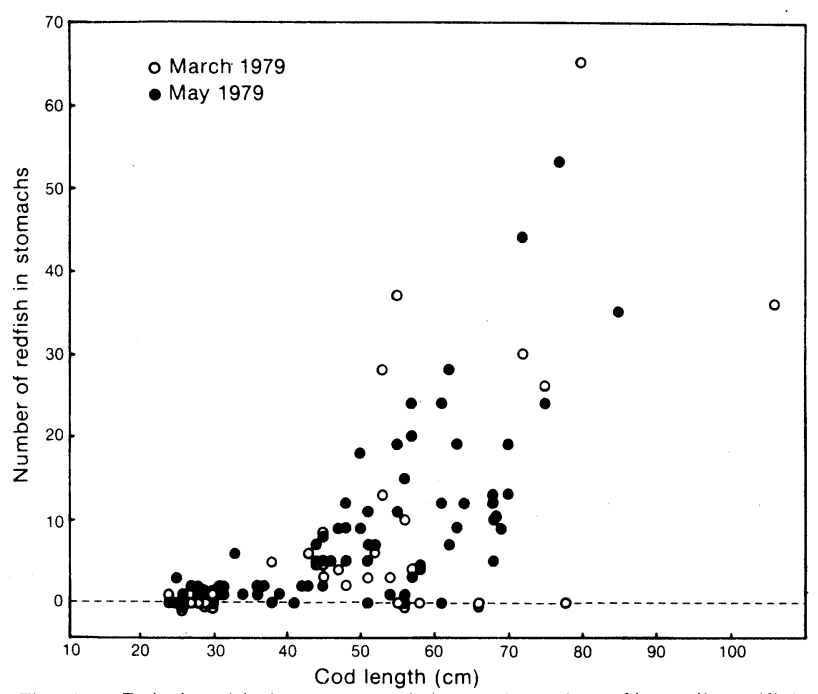

Fig. 1. Relationship between cod size and number of juvenile redfish $(<10 \mathrm{~cm}$ long) found in cod stomachs, from two trawl catches in 200-300 $\mathrm{m}$ on the southwestern part of Flemish Cap in the spring of 1979 . 
TABLE 2. Stratified arithmetic mean number per tow of small redfish in trawl catches and mean number of small redfish per stomach in cod $\geqslant 30 \mathrm{~cm}$ on Flemish Cap, 1978-82.

\begin{tabular}{lcccrr}
\hline \hline Length & 1978 & \multicolumn{7}{c}{1979} & 1980 & 1981 & 1982 \\
\hline \multicolumn{5}{c}{ Trawl catches $^{\mathrm{a}}$} \\
$6 \mathrm{~cm}$ & - & 0.18 & 0.01 & 0.04 & 1.14 \\
7 & - & 2.10 & 0.05 & 45.28 & 66.84 \\
8 & - & 1.75 & 0.25 & 43.26 & 100.43 \\
9 & 0.01 & 0.23 & 0.20 & 0.07 & 14.53 \\
10 & 0.03 & 0.43 & 0.28 & 0.05 & 101.27 \\
11 & 0.10 & 1.66 & 0.11 & 0.14 & 250.83 \\
12 & 0.40 & 0.84 & 0.13 & 0.23 & 182.92 \\
13 & 1.00 & 0.27 & 0.45 & 0.20 & 40.15 \\
14 & 1.65 & 0.62 & 0.37 & 0.17 & 1.69 \\
15 & 1.66 & 1.03 & 0.30 & 0.11 & 0.56 \\
\hline \multicolumn{7}{c}{ Cod stomach } \\
& & & & & \\
$45-89 \mathrm{~mm}$ & 0.12 & 2.85 & 0.04 & 3.51 & 1.35 \\
$90-124$ & - & 0.28 & - & 0.02 & 1.08 \\
\hline
\end{tabular}

a See Table 1 for summary information on surveys and sampling.

\section{Results}

\section{Redfish length frequencies}

The length frequencies of juvenile redfish caught by trawling (Table 2) and recovered from cod stomachs (Fig. 2) in 1982 revealed two distinct modes, which are assumed to represent successive yearclasses. The modal group of smaller fish was well represented in the cod stomachs in 1979 and in both the catches and the cod stomachs in 1981 (Table 2).

There is good agreement on the sizes of redfish from the two sources. The modal lengths from trawl catches were $7-8 \mathrm{~cm}$ and $11-12 \mathrm{~cm}$ fork length (Table 2). Redfish, measured as total length, from cod stomachs were slightly smaller, with modal groups at 65-74 $\mathrm{mm}$ and 100-114 mm (Fig. 2). Part of this difference was due to shrinkage of redfish in cod stomachs during preservation in formalin and the difficulty of obtaining length measurements of specimens with frayed tails resulting from digestion, but there may also be selection toward larger redfish by the trawl or toward smaller redfish by the cod, particularly the small ones $(30-40 \mathrm{~cm})$.

\section{Distribution}

Juvenile redfish were caught primarily in depths of 200-300 m (Fig. 3). The smaller fish $(7-8 \mathrm{~cm})$ were most abundant on the southwestern part of Flemish Cap in 1979 and 1981 (Fig. 3A, B), but in 1982 they were more broadly distributed over the southern part of the bank and there was a small concentration in the north (Fig. $3 \mathrm{C})$. The larger fish $(10-13 \mathrm{~cm})$, found in abundance only in 1982, were most abundant in an arc across the southern part of the bank, but there were a few large catches in the northern sector (Fig. 3D).

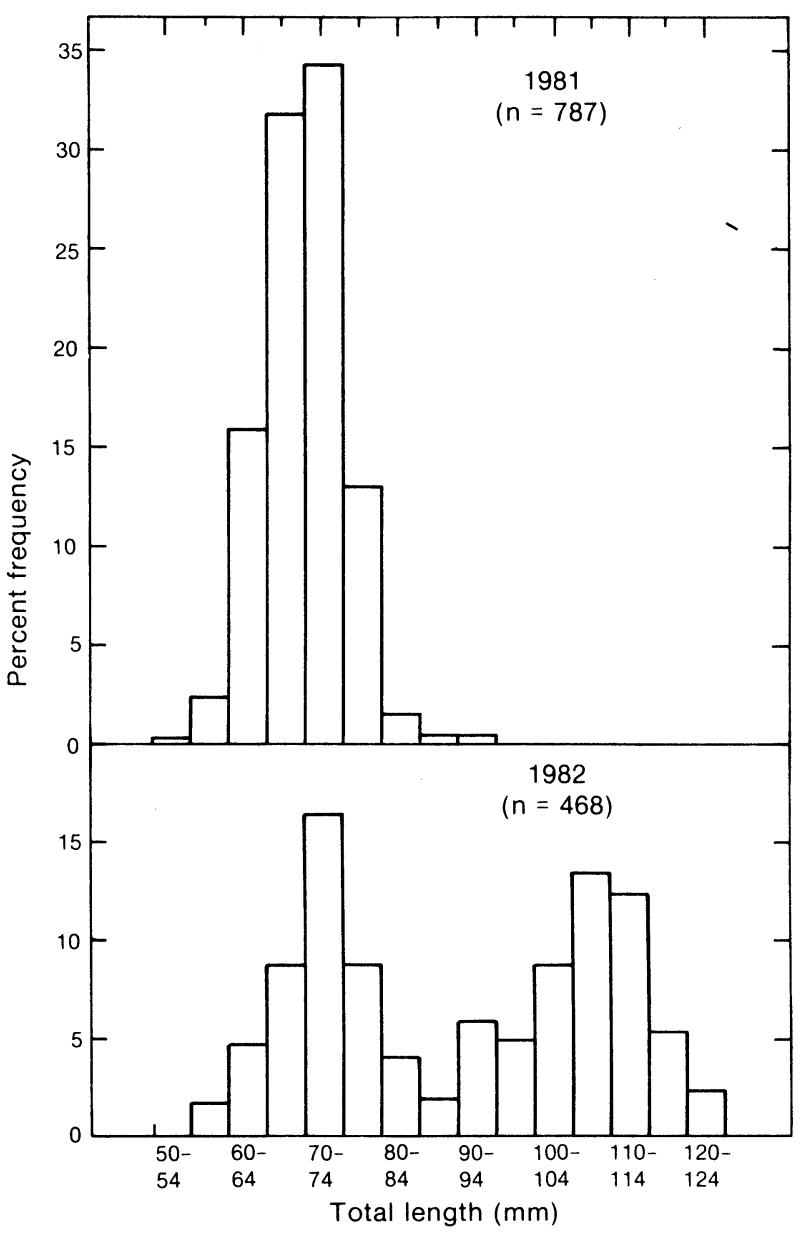

Fig. 2. Length frequencies of juvenile redfish from stomachs of cod caught on Flemish Cap during winter surveys of 1981 and 1982.

The occurrence of juvenile redfish in cod stomachs (Fig. 4) revealed distributions similar to those derived from the trawl catches, except that they were found in stomachs from many more locations. This was particularly apparent in 1981, when small redfish were caught in very few sets on the northwestern and central areas of the bank (Fig. 3B), but their presence in these areas was revealed by examination of cod stomachs (Fig. 4B).

\section{Abundance}

Juvenile redfish were $7-8 \mathrm{~cm}$ in length when first caught during the January-February bottom-trawl surveys (Table 2). The catch rate of juveniles of this size group in 1982 was approximately twice as large as in 1981, and these rates were greater than that for 1979 . The year-class which appeared in 1979 was not abundant in later years but that which appeared in 1981 was very numerous as $10-13 \mathrm{~cm}$ fish in 1982 . Catches of 7-8 $\mathrm{cm}$ redfish were very small in 1978 and 1980. 


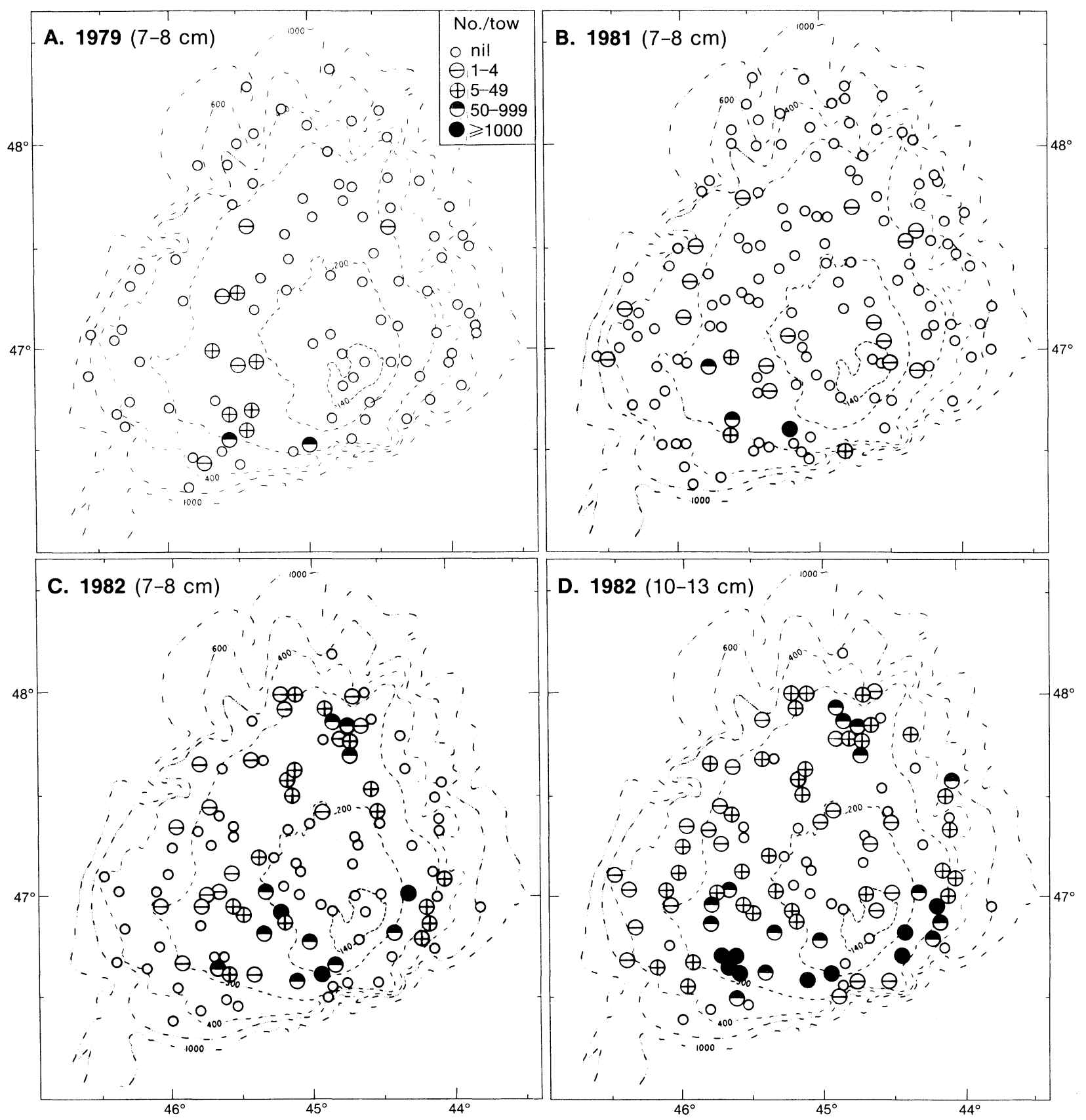

Fig. 3. Distribution of juvenile redfish in trawl catches during winter surveys of 1979, 1981 and 1982.

The pattern of weak and strong year-classes revealed by trawl catches was also evident in the recoveries of redfish from cod stomachs, with abundant groups of 45-89 mm fish in 1979, 1981 and 1982 (Table 2). However, the year-class which appeared in 1982 had the lowest recovery rate rather than the highest. The year-class which appeared in 1979 was not found in later years. The year-class which appeared in 1981 was found in the following year but at a recovery rate less than that for the new year-class in 1982.

\section{Discussion}

\section{Length distribution and age interpretation}

The length frequency of juvenile redfish caught on Flemish Cap in the winter of 1982 revealed two distinct modal groups at $7-8 \mathrm{~cm}$ and $11-12 \mathrm{~cm}$ fork length. The ages of these fish are uncertain. Small redfish $(7-8 \mathrm{~cm})$ caught in 1979 and 1981 were determined by interpretation of otolith annuli to be 2-year-olds (Gavaris and Legge, MS 1981). However, small redfish intermediate 

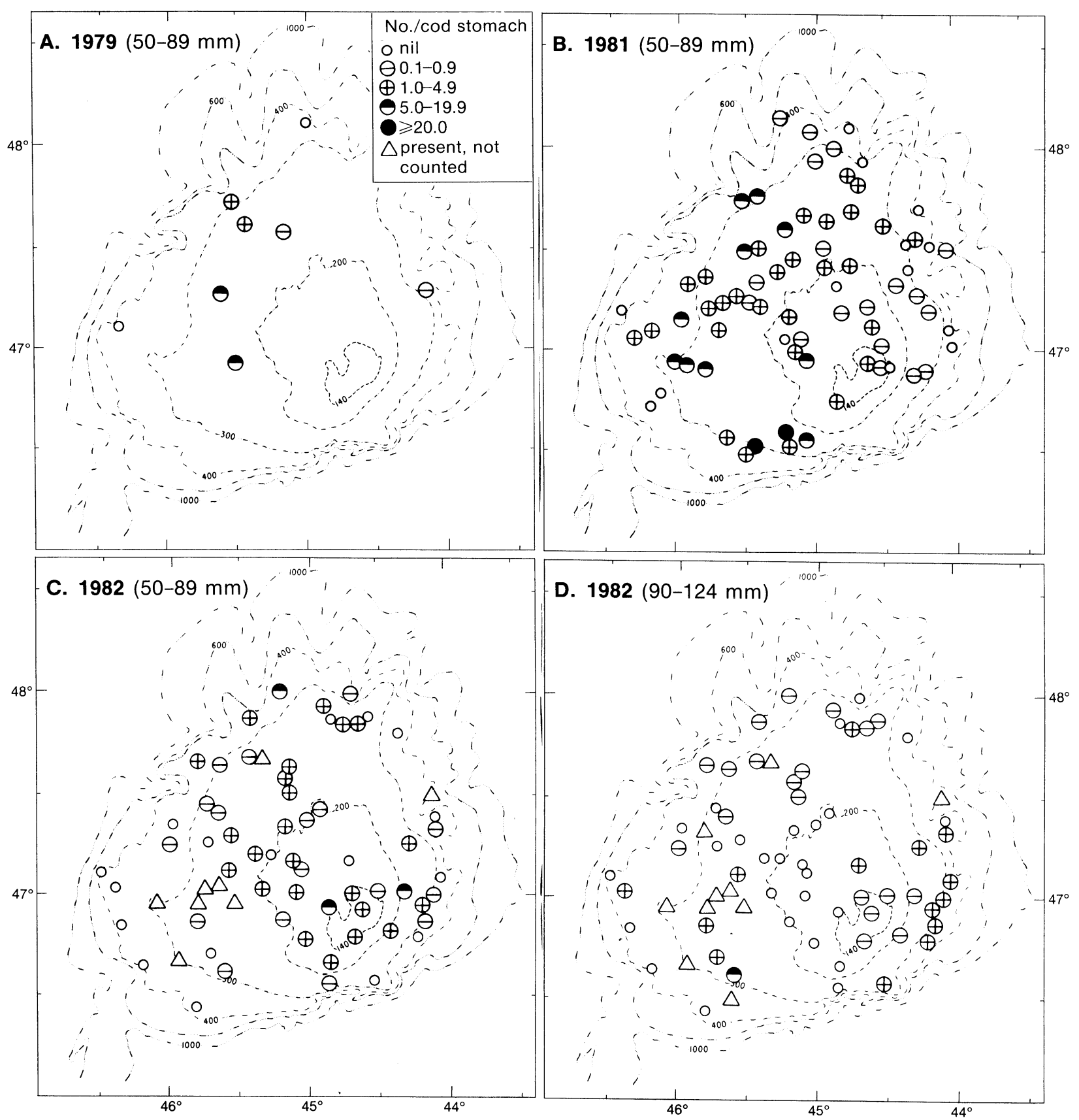

D. $1982(90-124 \mathrm{~mm})$

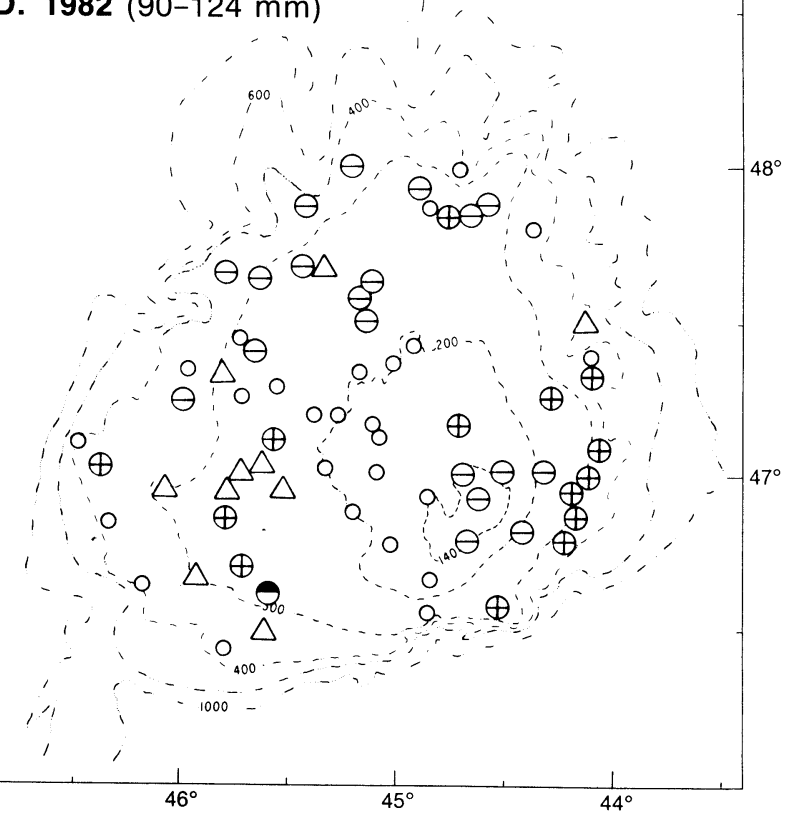

Fig. 4. Distribution of juvenile redfish as determined for examination of cod stomachs collected during the winter surveys of 1979,1981 and 1982. (Symbols pertain to sets from which two or more cod were examined.)

in modal size between larvae $(2 \mathrm{~cm} \mathrm{SL})$ caught in larval sampling gear in summer (Anderson and Akenhead, 1981) and juveniles (7-8 cm FL) caught by bottomtrawl in January-February have not been taken on Flemish Cap in plankton gear, in lined otter trawls or from cod stomachs. Thus, if 7-8 cm redfish are 2-yearolds, they are not captured as 1-year-olds by any collecting device currently used on Flemish Cap. If, however, the 7-8 cm redfish are 1-year-olds, their growth is consistent with interpretation of events in the Gulf of Maine, where young redfish are thought to settle to the bottom at an age of 4-5 months and an average length of 4-5 cm (Kelly and Barker, 1961). More recently, an isolated dominant group of redfish, assumed to be the 1971 year-class, was first recorded in a bottom-trawl survey in the Gulf of Maine in the autumn of 1971 at a modal length of $6 \mathrm{~cm}$ (Mayo et al., 1981).

For ease of discussion in the remainder of this paper, the modal groups of $7-8 \mathrm{~cm}$ and $11-12 \mathrm{~cm}$ redfish captured in winter are referred to as age-groups 1 
and 2 respectively, although the actual age of the fish in each modal group may be one year older. Resolution of the ageing problem is essential for determining how successful each year-class has been in surviving from the pelagic larval phase to the demersal early juvenile phase (i.e. in determining the correspondence between larvae collected in spring-summer ichthyoplankton surveys and juveniles collected in JanuaryFebruary bottom-trawl surveys).

\section{Distribution}

Data from bottom-trawl surveys and from examination of stomachs of cod caught during these surveys revealed somewhat different but complementary information on distribution of juvenile redfish. Bottomtrawling seemed to be more successful than cod stomachs in demonstrating areas of high density, probably because there is an upper limit to the ingestive capacity of cod. However, cod-stomach examination revealed the presence of juvenile redfish at more locations than trawling, especially in 1981 (Fig. 3B, $4 B$ ), indicating that a predator may be a better collecting device than a bottom trawl in areas where the density of the target species is low. Distribution patterns of prey inferred from their occurrence in stomachs of predators are suspect, for it is possible that the predator may move a considerable distance before digestion renders the prey unrecognizable. This possibility cannot be assessed in the present study because the rate of digestion at low temperature $\left(3^{\circ}\right.$ to $\left.4^{\circ} \mathrm{C}\right)$ and the movements (speed and direction) of cod are unknown. However, many redfish recovered from cod stomachs in regions where no redfish were caught in the trawl were in early stages of digestion.

Data from examination of cod stomachs in 1982 were not as informative as in previous years in elucidating the distribution of juvenile redfish, partly due to the presence of two redfish age-groups. If cod feed to satiation, the number of individuals of each age-group ingested will be less than when there is only one agegroup. Of probably greater significance were the small average size and very low abundance of cod in 1982 (NAFO, 1982), for the number of redfish ingested is a function of cod size, and the degree of spatial overlap of cod and juvenile redfish is a function of cod population size. In 1982, many sets with large catches of juvenile redfish (Fig. 3C, D) yielded fewer than two cod larger than $29 \mathrm{~cm}$ in length (Fig. 4C, D).

In all years of investigation, juvenile redfish were observed to be most abundant in depths of $200-300 \mathrm{~m}$. In 1982, when age-groups 1 and 2 were present, there was considerable overlap in distribution of the two groups, with both groups sometimes occurring abundantly in the catch and in cod stomachs from the same set. However, 2-year-olds tended to be distributed deeper than 1-year-olds (Fig. 3C, D). The reason for the greater concentration of juvenile redfish on the southern and particularly the southwestern part of the bank is unknown.

\section{Abundance and year-class strength}

The relative strengths of the year-classes cannot be determined with confidence from either the trawl catches or the recoveries from cod stomachs. Trawl catches tend to be greatly skewed; for example, the difference in catch rates in 1979 and 1981 (Table 2) was due primarily to one very large catch of 9,267 individuals in 1981. The recovery rate of young redfish from cod stomachs is influenced by several factors, including the size of cod examined, the degree of spatial overlap of cod and juvenile redfish, and the availability of other suitable prey. Furthermore, the relationship between the numbers of redfish found in cod stomachs and the abundance of redfish is unknown. If redfish are among the preferred prey of cod on Flemish Cap, there may be an initial rapid increase in number of prey taken with increasing redfish density, followed by a slower increase to the satiation level. In this situation, the degree of predation may be highly sensitive to changes in year-class strength of prey at low levels of prey abundance, somewhat insensitive at high abundance of prey, and highly dependent on availability of alternate preferred prey, especially adjacent year-classes. The effect of a second redfish year-class as alternate prey was evident in 1982, when predation was almost evenly divided between the two year-classes (Table 2).

Even with these limitations, it is clear that the 1977 and 1979 year-classes were not abundant as 1-yearolds. The 1978 year-class appeared to be strong from cod-stomach examination but only of moderate strength in the trawl catches. It declined to low abundance as 2 -year-olds in 1980 . The 1980 year-class was strong as 1-year-olds in both trawl catches and cod stomachs and was caught in even greater numbers as 2 -year-olds in 1982. The 1981 year-class was apparently very strong as 1 -year-olds. This apparent variation in year-class success of redfish may be attributable in part to predation on juveniles. The 1977 and 1979 year-classes presumably did not pass successfully through the larval stage. The 1978 year-class was sufficiently successful in the larval stage to be abundant as early juveniles. It was found in large numbers in cod stomachs during three surveys in 1979 [January-February (Table 3), and March and May (Fig. 1)] but its abundance was very low by January 1980. The demise of this year-class was probably due to predation by cod and possibly other predators, including adult redfish (Kashintsev, 1962; Gavaris and Legge, MS 1981), but other factors such as inadequate food supply and unfavorable environmental conditions (Akenhead, MS 1978) may have contributed. 
The 1980 year-class was abundant as 1-year-olds, but, unlike the 1978 year-class, it survived in large numbers as 2-year-olds. If predation is the major cause of mortality in juvenile redfish, success of the 1980 year-class may be due to (a) their survival in sufficiently large numbers from the larval stage as to swamp the ingestive capacity of predators, or (b) decreased predation on early juveniles as a result of a significant decline in cod abundance (NAFO, 1982) and the appearance of a strong succeeding year-class as alternate prey. The apparent initial success of the 1981 year-class, as evidenced in the 1982 catches, could also have been due to high survival in the larval stage or moderate survival in the larval stage coupled with reduced predation in the early juvenile stage. It is unlikely that these various possibilities can be distinguished without estimates of absolute abundance in the early demersal stage (perhaps October or November of the first year) and seasonal information on mortality due to predation.

Although predation by cod may be important in reducing the abundance of juvenile redfish, it is not yet clear that such predation significantly affects yearclass strength. The prey's mortality rate may vary with the abundance and size distribution of the predator, the growth rate of prey, and the availability of alternate prey, particularly those which are equally or more highly preferred by the predator. The influence of abiotic factors on the ability of the predator to find the prey may also be important. Furthermore, because predators can feed only to satiation, prey year-classes which are relatively weak following the larval stage may experience a higher mortality rate than those which are relatively strong. Thus, predation on juveniles should influence ultimate year-class strength and, in particular, accentuate the weakness of poor year-classes.

Evidence that predation on juveniles may not be the major factor affecting redfish recruitment is found in the synchronous appearance of strong year-classes over wide geographic areas. Juvenile redfish of sizes similar to those found on Flemish Cap in the winter of 1982 (modal lengths of $7-8 \mathrm{~cm}$ and $11-12 \mathrm{~cm}$ ) were also abundant in catches during a research bottom-trawl survey of the Scotian Shelf (Div. 4VWX) in March-April 1982 (Zwanenburg et al., MS 1982). Also, juvenile redfish $(7-8 \mathrm{~cm})$ were abundant in the Gulf of St. Lawrence (Div. 4RS) in the winter of 1981, and groups with modal lengths at 9 and $12 \mathrm{~cm}$ were abundant on St. Pierre Bank (Div. 3Ps) in the spring of 1982 (unpubl. data, Northwest Atlantic Fisheries Centre, St. John's, Newfoundland). This widespread appearance of recent strong year-classes represents what may become the first successful recruitment to the redfish stocks since approximately 1970-72, when a series of relatively strong year-classes appeared (Atkinson et al., MS 1981; Gavaris, MS 1981; McKone et al., MS 1981). In the
Gulf of Maine-Georges Bank area (Subarea 5), there was a single isolated successful year-class in 1971 (Mayo, 1980). The synchronous appearance of strong redfish year-classes over wide geographic areas supports the hypothesis that the major factors determining year-class strength in redfish operate at the larval stage and are related to physical phenomena occurring on a broad scale.

\section{Acknowledgements}

We thank C. Mullins who examined the cod stomachs in 1981 and 1982, summarized most of the data and helped to prepare the illustrations, R. Green and $\mathrm{H}$. Mullett who helped with the illustrations, and J. T. Anderson, D. B. Atkinson and J. C. Rice who reviewed the initial manuscript. We particularly thank $R$. Wells and N. Batten, who were in charge of the Gadus Atlantica cruises, and the technicians who collected the stomachs.

\section{References}

AKENHEAD, S. A. MS 1978. Report of the Canadian planning group of the Flemish Cap international experiment meeting. St. John's, Newfoundland, 12-14 September 1977. ICNAF Res. Doc., No. 80 , Serial No. 5267

ANDERSON, J. T., and S. A. AKENHEAD. 1981. Distribution and abundance of redfish and cod larvae on Flemish Cap in 1978 and 1979. NAFO Sci. Coun. Studies, 1: 57-63.

ATKINSON, D. B., W. E. LEGGE, and P. STEAD. MS 1981. The redfish stock in NAFO Division 3P. Can. Atl. Fish. Sci. Adv. Comm., Res. Doc., No. $81 / 59$.

BAGENAL, T. B. 1977. Effects of fisheries on Eurasian perch (Perca fluviatilis) in Windermere. J. Fish. Res. Bd. Canada, 34: 1764-1768.

BAKUN, A., and R. H. PARRISH. 1980. Environmental inputs to fishery population models for eastern boundary current regions. In Workshop on the effects of environmental variation on the survival of larval pelagic fishes. G. D. Sharp (ed.). FAO/IOC Workshop Report, 28: 67-104.

FORNEY, J. L. 1976. Year-class formation in the walleye (Stizostedion vitreum vitreum) population of Oneida Lake, New York, 1966-73. J. Fish. Res. Bd. Canada, 33: 783-792.

GAVARIS, C. A. MS 1981. An assessment of redfish on the Flemish Cap. NAFO SCR Doc., No. 53, Serial No. N337.

GAVARIS, C. A., and W. E. LEGGE. MS 1981. Distribution and abundance of small redfish on the Flemish Cap. NAFO SCR Doc., No. 119, Serial No. N425.

ICNAF. 1977. Report of Standing Committee on Research and Statistics, Annual Meeting, May-June 1977. ICNAF Redbook, 1977: 35-87.

KASHINTSEV, M. L. 1962. Some notes on rosefish feeding in the Newfoundland area. In Soviet Fishery Investigations in the Northwest Atlantic, Yu. Yu. Marti (ed.), VNIRO-PINRO, Moscow. (Transl. from Russian by the Israel Prog. for Sci. Transl., 1963, p. 256-265.)

KELLY, G. F., and A. M. BARKER. 1961. Vertical distribution of young redfish in the Gulf of Maine. ICNAF Spec. Publ., 3: 220-233.

LILLY, G. R. 1980. Year-class strength of redfish and growth of cod on Flemish Cap. ICNAF Sel. Papers, 6: 35-39.

MS 1981. Distribution and relative abundance of juvenile redfish on the Flemish Cap in 1978-81 based on recoveries from cod 
stomachs. NAFO SCR Doc., No. 118, Serial No. N424.

MANN, R. H. K. 1982. The annual food consumption and prey preferences of pike (Esox lucius) in the River Frome, Dorset. J. Anim. Ecol., 51: 81-95.

MAYO, R. K. 1980. Exploitation of redfish, Sebastes marinus (L.), in the Gulf of Maine-Georges Bank region, with particular reference to the 1971 year-class. J. Northw. Atl. Fish. Sci., 1: 21-37.

MAYO, R. K., V. M. GIFFORD, and A. JEARLD Jr. 1981. Age validation of redfish, Sebastes marinus (L.), from the Gulf of Maine-Georges Bank region. J. Northw. Atl. Fish. Sci., 2: 13-19.

MCKONE, W. D., C. GAVARIS, and W. E. LEGGE. MS 1981. Redfish assessment for Divisions 4RST. Can. Atl. Fish. Sci. Adv. Comm., Res. Doc., No. 81/58.

NAFO. 1982. Report of Scientific Council, Regular Meeting, June 1982. NAFO Sci. Coun. Rep., 1982 (in press).

NI, I-H. 1981a. Separation of sharp-beaked redfishes, Sebastes fasciatus and S. mentella, from northeastern Grand Bank by morphology of extrinsic gasbladder musculature. J. Northw. Atl. Fish. Sci., 2: $7-12$.

1981b. Numerical classification of sharp-beaked redfishes, Sebastes mentella and S. fasciatus, from northeastern Grand Bank. Can. J. Fish. Aquat. Sci., 38: 873-879.

1982. Meristic variation in beaked redfishes, Sebastes mentella and S. fasciatus, in the Northwest Atlantic. Can. J. Fish.
Aquat. Sci., 39: 1664-1685.

MS 1982. Meristic variation in golden redfish, Sebastes marinus, in the Northwest Atlantic. NAFO SCRDoc., No. 82, Serial No. N590.

NI, I-H., and W. D. McKONE. 1983. The distribution and concentration of redfishes in Newfoundland and Labrador waters. NAFO Sci. Coun. Studies, 6 (in press).

NIELSEN, L. A. 1980. Effects of walleye (Stizostedion vitreum vitreum) predation on juvenile mortality and recruitment of yellow perch (Perca flavescens) in Oneida Lake, New York. Can. J. Fish. Aquat. Sci., 37: 11-19.

PITT, T.K., R. WELLS, and W. D. McKONE. 1981. A critique of research vessel otter trawl surveys by the St. John's Research and Resource Services. Can. Spec. Publ. Fish. Aquat. Sci., 58: 42-61.

POWER, D. J., and I-H. NI. 1982. Morphology of the extrinsic gasbladder musculature in the golden redfish, Sebastes marinus. $J$ Northw. Atl. Fish. Sci., this volume, p. 165-168.

TEMPLEMAN, W. 1976. Biological and oceanographic background of Flemish Cap as an area for research on the reasons for year-class success and failure in cod and redfish. ICNAF Res. Bull., 12: 91-117.

ZWANENBURG, K., T. KENCHINGTON, and M. L. DICKSON. MS 1982. 1982 status report on 4 VWX redfish. Can. Atl. Fish. Sci. Adv. Comm., Res. Doc., No. 82/11. 